\title{
Non-Audit Service and Audit Independence: Evidences from Iran
}

\author{
Mahdi Salehi \\ Assistant Professor, Accounting and Management Department \\ Zanjan University \\ D.N. 1 Nagilo Alley, Hidaj, Zanjan, Iran \\ Tel: 98-912-142-5323 E-mail: mahdi_salehi54@yahoo.com
}

\begin{abstract}
From recent years on, because of several reasons independence of auditor became undermined, so far some factors recognized that which impair independence, especially non-audit service so, in this condition may appear to affect to independence. The results of this study show that shareholders strongly agree that providing NAS by external auditors to the same clients strongly negatively affect to audit independence.
\end{abstract}

Keywords: Non-Audit Services (NAS), Auditor independence, Iran

\section{Introduction}

Until now, the auditor is an important element in the financial statement because the audit subjects financial statements, which are management's responsibility, to scrutiny on behalf of shareholders and creditors to whom management is accountable. The auditor is the independent link between management and those who rely on the financial statements for the decision-making. In that role, the auditor evaluates the judgments made by management in applying standards for the presentation of the financial information. Hence the audit profession, through its independent audit function, has playing an important role in enhancing a financial reporting process that facilitates the effective functioning of business environment. The public confidence in the reliability of issuer's financial statements that is provided by the programme of independent audits encourages investment in securities issued by companies. This sense of confidence depends on reasonable investors perceiving auditors as independent professionals who have neither, mutual nor conflicting interests with their audit clients. Accordingly, users of financial statements expect auditor to bring to the financial reporting process technical competence, integrity, independence, and to prevent the issuance misleading financial statements. But because of recent audit failures surrounding such as Enron, Waste Management, Cendant, Sunbeam and others, the audit practice is undermined.

Today's auditing and accounting firms also performs other accounting related services, such as tax services, and provide a wide array of non accounting and non auditing services, such as management advisory or consulting services.

Because of those services, serious questions were raised concerning the activity and accountability of auditor's performance. These questions arose in large part from a series of unexpected failures of large companies as well as disclosures of questionable and legal or illegal payment to auditors as well as non-audit services.

\section{Independence}

One of the key factors of the auditor's is independence, without independence users of financial statements cannot rely on the auditor's report. In short, the external system of audit, with its final product, the audit opinion, adds credibility to the financial statements so that users can rely on the information presented and, as a result, the entire system of financial reporting enhanced (Sucher et al. 2004). Furthermore, independence is the core of this system.

The concept of audit independence is fuzzy, the rules governing it are complex and burdensome, and a reexamination is long overdue (Elliott and Jacabson, 1992).

DeAngelo (1981) defined auditor independence as "the conditioner probability of reporting a discovered bridge".

Arens et al. (1999) defined "independence in auditing" as taking an unbiased viewpoint in the performance of audit tests, the evaluations of the results and the issuance of audit reports. Independence includes the qualities of integrity, objectivity and impartiality. Knapp (1985) states the independence in a different angle. He viewed it as "The ability to resist client pressure". According to Flint (1988)"Independence, therefore, is not a concept which lends itself to 
universal constitution prescription, but one for which the constitution prescription will depend on what is necessary to satisfy the criteria of independence in the particular circumstances".

The ISB (2000) defines independence as: Freedom from pressures and other factors that impair, or are perceived to impair, an auditor's willingness to exercise objectivity and integrity when performing an auditor is the absence of certain activities and relationships that may impair, or may be perceived to impair, an auditor's willingness to exercise objectivity and integrity when performing an audit (ISB, 2000, 44).

There are two approaches of audit independence have commonly been referred to as independence of fact and independence of appearance.

\subsection{Independence: in fact and appearance}

According to Mautz and Sharaf (1964) there are two aspects of independence: firstly, the real independence of the individual practitioner in the performance of his/her works and secondly, the apparent independence of auditors as a professional group. These two concepts of independence have been referred to as 'practitioner independence' and 'professional independence' respectively.

Independence may be a state of mind or a behavior. According to AUP 32, independence requires a freedom from bias, personal interest, prior commitment to an interest, or susceptibility to undue influence or pressure (AUP, 2001). This suggests that an auditor possessing the requisite state of mind will act in the correct fashion. In this context, auditors should not be independent in fact, but more importantly they should be seen to be independent in examining and attesting clients' financial statements (Stevenson 2002). Precisely, auditors are expected to be able to independently decide on reporting strategies without any influence from their clients' management (Cullinan, 2004).

Orren (1997) states that independence in fact refers to the actual, objective relationship between auditing firms and their clients whereas independence in appearance is the subjective stated of that relationship as perceived by the clients and the third parties. Church and Zhang, (2002) argue that independence in fact is necessary to enhance the reliability of financial statements. On other hand, independence in appearance is necessary to promote public confidence such that users will rely on audited financial statements.

The issues of independence in fact and appearance have also been acknowledged by the standard setting bodies. The AICPA acknowledged the importance of perceptions of auditor independence- 'Independent auditors should not only be independent in fact; they should avoid situations that may lead outsiders to doubt their independence. The current AICPA Code of Professional Conduct (1988) explicitly requires not only actual independence from audit clients but also the appearance of independence to third parties. The SEC defined independence in fact and independence in appearance as separate but equally necessary factors in establishing the auditor's objectivity and integrity when certifying financial statements filed with the commission by an issuer of securities.

According to Mautz and Sharaf (1964), there are three dimensions of auditor independence which can minimize or eliminate potential threats to the auditor's objectivity:

(I) Programming independence includes:

Freedom from managerial interference with the audit program; freedom from any interference with audit procedures; and freedom from any requirement for the review of the audit work other than which normally accompanies the audit process,

(II) Investigative independence en com passes:

free access to all records, procedures, and personnel relevant to the audit; active co-operation from management personnel during the audit examination; freedom from any management attempt to specify activities to be examined or to establish the acceptability of evidential matter; and freedom from personal interests on the part of the auditor leading to exclusions from or limitations on the audit examination.

(III) Reporting independence includes:

Freedom from any feeling of obligation to modify the impact or significance of reported facts; freedom from pressure to exclude significant matters from internal audit reports; avoidance of intentional or unintentional use of ambiguous language in the statement of facts, opinions, and recommendations and in their interpretations; and freedom from any attempt to overrule the auditor's judgment as to either facts or opinions in the internal audit report.

The immediate objective of the audit is to improve the reliability of information used for investment and credit decisions according to Elliott and Jacabson (1992) the principles of independence as follows:

Audit independence improves the cost - effectiveness of the capital market by reducing the likelihood of material bias by auditors that can undermine the quality of the audit. Therefore, they play vital role in economic sector. However, some factors may have negative affection to independence, which these factors should be identified by professionals and take sever action to reducing such a factors. 


\section{Factors affecting to independence}

Several situations may impair the auditor's independence, such as contingent fee arrangements, gifts, auditor's with personnel or operations, non-audit services (NAS), outsourcing, opinion shopping, reporting relationships, and others.

Among the factors that affect to auditor independence that have been studied are:

(1) The effects of gifts (pany and Reckers, 1980);

(2) The purchase discount arrangement (pany and Reckers, 1980);

(3) The audit firm size (Shockley, 1981; Gul, 1989);

(4) The provision of management advisory services (MAS) by the audit firm (Shockley, 1981; Knapp, 1985; Gul, 1989; Bartlett, 1993; Teoh and Lim, 1996; Abu Bakar et al 2005);

(5) The client's financial condition (Knapp, 1985; Gul, 1989; Gul and Tsui, 1992);

(6) The nature of conflict issue (Knapp, 1985);

(7) The audit firm's tenure (Shockley, 1981; Teoh and Lim, 1996);

(8) The degree of competition in the audit services market (Knapp, 1985; Gul, 1989);

(9) The size of the audit fees or relative client size (Gul and Tsui, 1992; Bartlett, 1993; Teoh and Lim, 1996; Pany and Reckers, 1980);

(10) The audit committee (Gul, 1989; Teoh and Lim, 1996); and

(11) Practicing non-audit services (NAS) by auditors (Beattie et al, 1999).

In this paper the author only attempted to clarify non-audit services and its affection to independence of auditors.

The audit failures that have been reported have led to major criticism of the auditing profession worldwide by exposing the weaknesses of the profession in term of safeguarding shareholders' and stockholders' interests (Brandon et al, 2004, Citron, 2003, Cullinan, 20004, Fearnley and Beattie, 2004, Ghosh and Moon, 2005, Gwilliam, 2003, Higson, 2003, Krishnan and Levine 2005); thus some of this criticism arose from non-audit service practices by auditors.

\section{Non-audit services}

It is found out that auditors believe that the auditors' work would be used as a guide for investment, valuation of companies, and in predicting, bankruptcy. Furthermore, the third party fell that there is strong relationship between the reliability of the auditor's work and the investment decision. Also the auditor's work facilitates the process of economic development through the presentation of reliable information concerning the financial position of the companies (Whadan et al, 2005). However, in recent years some auditors practicing non-audit services; therefore, the main question that arises when auditors provide or could provide both audit and non-audit services is whether the auditors are able to conduct their audits impartially, without being concerned about losing or failing to gain additional services, and the subsequent economic implications for the audit firm (Lee, 1993). As far as globalization in accounting and assurance service has also created the multidisciplinary nature of large audit firms (Brierley and Gwilliam, 2003). These multidisciplinary firms offer audit and non-audit services to audit clients and this have become one of the major concerns regarding the potential auditor independence dilemma (Quick and Rasmussen, 2005). The idea that auditor independence may be eroded via an increase in the auditor economic bond has long been recognized. Most attention has been directed at the possible impact on auditor independence of non-audit services. Although, concerns the impact of non-audit services on auditor independence are not new (Zeff, 2003, a, b).

The economic bonding between audit firms and their clients would influence auditor independence. It may be that the level of client pressure would increase and auditor becomes less concerned with the quality of internal control (Muhamad and Karbhari, 2006).

Although there are market-based incentives for auditors to remain independent, there are also forces that potentially threaten auditor independence. Specifically, regulators are concerned about two effects of non-audit services. One is a fear that non-audit service fees make auditors financially dependent on their clients, and hence less willing to stand up to management pressure for fear of losing their business. The other is that the consulting nature of many non-audit services put auditors in managerial role (Defond et al 2002). These concerns are summarized in the following quote from the SEC regulations mandating fee disclosures (SEC, 2000). Auditor's services relationship raises two types of independence concerns. First, the more the auditor has at stake in its dealing with the audit client, particularly when the non-audit services relationship has the potential to generate significant revenues on top of the audit relationship. Second, certain types of non-audit services, when provided by the auditor, create inherent conflicts that are incompatible with objectivity.

In the United States, the Sarbanes Oxley Act of 2002 implemented a ban on nine non-audit services as follows: 
1) Bookkeeping and other services related to the audit client's accounting records or financial statements;

2) Financial information systems design and implementation;

3) Appraisal or valuation services and fairness opinions;

4) Actuarial services;

5) Internal audit services;

6) Management functions;

7) Human resources;

8) Broker-dealer services; and Legal services.

In addition, a registered public accounting firms may only engage in another service if the activity is approved in advance by the audit committee.

In the view of the fact, regarding audit practices one of the fundamental importance in understanding the conflict of interest that arises from the provision of non audit services to audit clients is the fact that is so doing the audit firm is really serving two different set of clients; management consulting services and the audit committee, shareholders and all those who rely on the audited financials and the firm's opinion in deciding whether to invest in the case of audit (Levine and Kornish, 2000).

\section{Review of literature}

After several scandals at international and national dimensions especially after Enron Collapse professionals, academics, and researchers have focused on non-audit services. However, many writers maintain the NAS impair objectivity, as well as independence, whereas others argue that there exists no association between NAS and audit quality. In short, the findings of prior studies on impacts of NAS on audit quality are negative, positive, or have no effects.

\subsection{Studies indicating negative effect of NAS on auditor independence}

Several prior studies suggest that NAS has negative effects on auditor practices and auditor independence.

Antle (1984) considers auditor independence to be an auditor's freedom from management influence as desired by company's owners. He considered that since management controls the auditor's fee, an auditor can ignore independence in favor of management, unless a control mechanism is implemented.

A Survey carried out by Wines (1994) suggests that auditors receiving NAS fees are less likely to qualify their opinion than auditors that don't receive such fees, based on his empirical analysis of audit report issued between 1980 and 1989 by 76 companies publicity listed on Australian stock exchange. He found that auditors of companies with clean opinions received higher proportion of non audit fees than did auditors of companies with at least one qualification. In relation to management advisory services (MAS), Gul and Tsui (1991) conducted a survey, also using Australian companies, that provision of management advisory services affects the in formativeness of earnings. They found evidence that the explanatory power of earnings for returns is less for firms that provide MAS. Frankel et al (2002) found empirically that levels of discretionary accruals are higher for firms whose auditors provided NAS than for firms whose auditors do not provide such services.

According to Beeler and Hunton (2002) contingent economic rents such as potential non-audit revenue, increase unintentional bias in the judgments of auditors. They found experimentally that audit partner participants searched more supportively, weighted confirmatory evidence more heavily, and made more elaborate arguments in the presence of low balling and potential non-audit revenue than provision of audit, and NAS claimed that auditors would not perform their audit service objectively and that joint provision would impair perceived independence (Brandon et al, 2004; Frankel et al, 2002; Glezen and Miller, 1985; Jenkins and Krawczyk, 2001; Krishnan et al 2005; Dopuch et al 2003).

Frankel et al, (2002); Larcker and Richardson, (2004); found some evidence of potential links between NAS and earnings management measures.

Beck et al. (1988) argue that non-audit fees further increase the client auditor bond by increasing the portion of the audit firm is delivered from serving a client. Moreover further research has failed to find evidence that non-audit fees impair auditor independence where independence is peroxide for processing the propensity to issue modified auditor opinions (Defond et al. 2002), Geiger and Raghunandan 2003).

Hackenbrack and Elms (2002) revisit the ASR 250 fee disclosures and find negative association between stock returns and non-audit fees for sample companies with the highest ratio of non-audit fees. Brandon et al (2004) opponents to the Joint provision of audit an NAS claimed that auditors would not perform their audit services objectively and joint provision would impair perceived independence. Mitchel et al. (1993) believed that the joint provision of audit and NAS to audit clients would cause unfair competition due to the use of audit services to the same client. 


\subsection{Studies indicating no effect of NAS on auditors' independence}

Several prior studies suggest that NAS has no effects on auditor practices and auditor independence.

Glezen and Millar, (1985); Corless and Parker (1987); Wines, (1994); Kinney et al (2004); AShbough et al (2003), did not find systematic evidence showing that auditors violate their independence as a result of clients purchasing relatively more NAS. According to Frankel et, al (2002) several studies have re-examined the negative effects of NAS on audit quality, and found in his study that NAS has no effect on auditors' independence. Abdel-Khalik (1990) reported no significant difference in audit fees between clients purchasing audit service only and those purchasing both audit and NAS.

Using discretionary accruals (DA) as a surrogate for auditor objectivity, Reynolds et al. (2004) find no association between NAS and DA and conclude that little evidence exists supporting the negative effects of NAS on auditor's objectivity.

O'Keefe at el, (1994) extended Davis et al (1993); using disaggregated Labor hours by rank (Partner, Manager, senior and staff) for clients of a Big six firms in 1989, and using also the percentage of tax fees to audit fees and the percentage of management consulting fees to audit fees as independent variables. They fail to find evidence that audit effort reduces in a joint provision scenario. Palmrose (1999) found that less than one percent of auditor litigation has NAS as part of the basis on which the lawsuit are founded. Jenkins and Krawczyk (2001) asked 83 Big Five and 139 Non-Big Five accounting professionals and 101 investor participants to rate their perceptions of auditor independence, integrity, and objectivity for two scenarios in which an auditor provides neither NAS to one firm, nor nominal amount of NAS (3 percent of total client revenues) nor a material amount of NAS (40 percent) to another. Although they found investor's perceptions of independence and decisions on whether or not invest were not affected by either level of non-audit service provision. Investors (a non-big-professional) did consider the 40 percent level of NAS to be significant in their investment decisions.

Sori, (2006) investigated the perception of Malaysian auditors, loan officers and senior managers of public listed companies on the effect of joint provision of audit and NAS on auditor independence. The majority of the responses agreed with the provision of NAS to audit client by the audit engagement team. Pany and Reekers (1988) described the results of a survey of loan officers and financial analysts, which suggested that NAS does not impair independence. Chung and Kallapur (2003) report no statistically significant association between abnormal accruals and the ratio of client fees to total audit firm fees.

\subsection{Studies indicating positive effect of NAS on auditors' independence}

Several prior studies suggest that NAS has positive effects on auditor practices and auditor independence.

Gul (1989) studied the perceptions of bankers in New Zealand and found that the effect of provision of NAS was significantly and positively associated with auditor independence. Hussey (1999) reported that the majority of the UK finance directors that participated in his study suggested that joint provision of audit and NAS to audit clients should continue to be allowed. In Malaysia Gul and Yap (1984) reported that NAS provision increased their confidence in auditor independence. Arruanda (1999, p. 165) pointed out that joint provision of audit and NAS would reduce overall cost, raises the technical quality of auditing, enhance competition. This would ultimately increase auditor independence. Carltonand and Perloff (2005) emphasize that the outcome is a more efficient allocation of scarce resources without the need to duplicate efforts to recreate the required input. Kinney et al (2004) denoted knowledge of a client's information system and tax accounting could spill over to the audit, improve the information available to the auditor and thus improve audit quality which in turn would increase the probability that problems are discovered.

Auditor's concern for reputation (Benston 1975; Dopuch et al, 2003) and legal liability (Palmrose 1988; Shu, 2000) should drive auditors to maintain their independence. Larcker and Richardson (2004) also document relation between level of NAS fees and accrual, especially for firms with weak governance. Their results suggest that auditors of firms that purchase large NAS are less likely to allow firm to make choices that lead to large abnormal accruals. They interpret their findings as suggesting that auditors working for firms with weak governance may play a more important role in the governance process in limiting choices of abnormal accruals and that enhanced knowledge through NAS has mere incremental positive effect on audit quality.

Ghosh et.al (2006) studied 8940 firm-year for observation over the (2000-2002) period and found the NAS fees ratio (ratio of NAS to total fees from the given clients) is negative associated with Earning Response Coefficients (ERC). Sharama (2006) studied the impact of audit providing NAS and audit-firm tenure on audit efficiency. He was opposed to restricting regulations on the joint provision of audit and NAS. His studies provided evidence demonstrates an increase in the amount of the provision of NAS, as a result of which the audit lag reduced. He also provides evidence that demonstrates extended audit-firm tenure reduces audit lag while shorter audit-firm tenure increases audit lag. Gore et al. (2001) report a positive association between the provision of non-audit services and earnings management in U.K companies, suggesting that auditors' reporting standards are affected by whether the auditor also provides non-audit 
services to the audit client. Lennox (1999) suggests that NAS increases auditors' knowledge on clients as well as the probability of discovering problems. Their empirical data, collected from UK firms, show a significant, though weak, positive relationship between NAS fees and auditors, a surrogate for audit quality.

\section{Research methodology}

According to the above literature the objectives of this study is reaction of auditors, and shareholders regarding to NAS and consulting services provided by the auditors to the clients. So far accurate answer to this question, the author design and developed a questionnaire based on method used in previous researchers.

The questionnaire contains two parts namely (A) bio-data and (B) this section includes 9 questions regarding to the rejection level of NAS by auditors and shareholders in Iran. The measure instrument of the statements is a Five-Point Likert type scale anchored "strongly disagree" (1) and "strongly agree" (5). To test for the significant NAS affection to audit independence between two parties of respondent, Mann-Whitney $U$ test is used which is non-parametric equivalent to the t-test, considered appropriate for ordinal measurements, such as the Likert scales employed in this study. It tests whether two independent samples are from the same population.

To ensure comparability with prior research findings, subjects used in previous studies were selected two groups were identified: auditors, and private shareholders. All groups have legitimate interests in the role of auditors.

\section{Results of the study}

In this section, the authors report the empirical findings of the statistical analysis for NAS affection to audit independence. For this purpose, 227 questioners from auditors and 261 questioners from shareholders were collected, which totally became 488 useable questionnaires in Tehran on the date of 2007. The all-statistical analyses were performed with the SPSS package software.

\subsection{Demographics of respondent groups}

The Table 1 shows that from 227 auditors are $78 \%$ graduate, 21\% master, and almost $1 \% \mathrm{PhD}$ qualification, whereas from 261 shareholders $90 \%$ have graduate, and $10 \%$ master qualification. According to this table, the auditors have higher auditing and accounting education than shareholders.

\section{Insert Table 1}

With regard to Table 2, 98\% auditors and almost $60 \%$ shareholders passed auditing courses. Also $100 \%$ auditors have accounting and auditing experience, while as the table shows $55 \%$ bankers have accounting and auditing experience.

\section{Insert Table 2}

Even though the accounting profession and the auditing standards uphold the independence of auditor, it is commonly observed that the independence of auditors is reduced because of NAS. It is generally believed that payment for non-audit services affect the independence of the auditor. In Table 3, some factors affecting auditor independence was tested. Highest mean value was assigned to financial information systems design levels with the values of 3.57 and 2.91 by shareholders and auditors respectively.

\section{Insert Table 3}

The test shows that there were significant differences between the shareholders and auditors opinions value of all the variables $\mathrm{Z}=0.000(<0.05)$ except Bookkeeping and actuarial services $(>0.05)$.

\section{Insert Table 4}

Table 4 highlights the statistical results of the respondents of the sample respondents with regard to NAS affection to audit independence. The management function by external auditors was assigned the overall mean value of 3.92 by shareholders as against the auditors mean value of 3.18 resulting in the differences of 0.74 . regarding to human resource shareholders belies that it will damaged audit independence by mean value of 3.94 as against the auditors not very agree with them by mean value of 3.48. Regarding statement No. 3 table 4 shareholders strongly believes that it will impaired audit independence by mean value of 3.62 as against auditors only agree with little area by mean value of 3.05.

The test shows that there were significant differences between the shareholders opinions and auditors opinions value of all the variables $\mathrm{Z}=0.000(<0.05)$.

\section{Conclusion}

The auditing profession is organized around central several conflicts. The client hires the auditor and pays the fees but the auditor is supposed to conduct the audit in an independent fashion adhering to the professions independence. Any factor may affect to audit independence should be eliminated. The results of this study showed that shareholders strongly believe that NAS impair audit independence. As previous studies also confirmed this results of study. For example a Survey carried out by Wines (1994) Gul and Tsui (1991) Frankel et al (2002) they got same results in different countries. According to Beeler and Hunton (2002) contingent economic rents such as potential non-audit 
revenue, increase unintentional bias in the judgments of auditors. Frankel et al, (2002); Larcker and Richardson, (2004); found some evidence of potential links between NAS and earnings management measures.

Beck et al. (1988) argue that non-audit fees further increase the client auditor bond by increasing the portion of the audit firm is delivered from serving a client. Moreover further research has failed to find evidence that non-audit fees impair auditor independence where independence is peroxide for processing the propensity to issue modified auditor opinions (Defond et al. 2002), Geiger and Raghunandan 2003).

Hackenbrack and Elms (2002) revisit the ASR 250 fee disclosures and find negative association between stock returns and non-audit fees for sample companies with the highest ratio of non-audit fees. Brandon et al (2004) opponents to the Joint provision of audit an NAS claimed that auditors would not perform their audit services objectively and joint provision would impair perceived independence. Mitchel et al. (1993) believed that the joint provision of audit and NAS to audit clients would cause unfair competition due to the use of audit services to the same client.

Furthermore, research results an internal separation of the auditing and the consulting function within the same audit firm is not viewed as beneficial in Iran.

\section{References}

Abdel Khalik, A.R. (1990). The Jointers of Audit Fees and Demand for MAS: A Self Selection Analysis. Contemporary Accounting Research, Vol. 6, No. 2, pp. 295-322.

Abu Bakar, A,. Bdul Rahman, A., and, Abdul Rashid, H. (2005). Factors Influencing Auditor Independence: Malaysian Loan Officers' Perceptions. Managerial Accounting, Vol. 20, No. 8, pp. 804-822.

AICPA, (1988). Code of Professional Conduct: Rule 100, American Institute of Certified Public Accountants. [Online] Available: www.aicpa.org

Antle, R (1984). Auditor Independence. Journal of Accounting Research, Vol. 22, No. (1), spring, pp. 1-20.

Arens, A., Loebbecke, J., Iskandar, T., Susela, S., Isa, and Boh, M. (1999). Auditing in Malaysia: An Integrated Approach, Prentice-Hall, Selangor.

Arruanda, B. (1999). The Provision of Non-Audit Services by Auditors: Let the Market Evolve and Decide International. Review of Law and Economics, Vol. 19, pp. 513-531.

Bartlett, R.W. (1993). A Scale of Perceived Independence: New Evidence on an Old Concept. Accounting, Auditing \& Accountability Journal, Vol. 6, No. 2, pp. 52-67.

Beattie, V. Fearnley and Brandt, R. (1999). Perception of Auditor independence: UK Evidence. Journal of International Accounting, Auditing and Taxation, Vol. 8, No.1, pp. 67-107.

Beck, P. J., Frecka, T. J., \& Solomon, I. (1988). A model of the market for MAS and audit services: Knowledge spillovers and auditor-auditee bonding. Journal of Accounting Literature, pp. 50-64.

Beeler, J. and Hunton, J. (2002). Contingent Economic Rents: Insidious Threats to Auditor Independence. Advances in Accounting Behavioral Research, Vol. 5, pp. 21-50.

Brandon, D., Crabtree, A., and Maher, J (2004). Non-Audit Fees, Auditor Independence and Bond Ratings. Auditing: A Journal of Theory and Practice, Vol. 23, No. 2, pp. 89-103.

Brandon, D.M. Crabtree, A.D. and Maher, J.J. (2004). Non-Audit Fees, Auditor Independence and Bond Ratings. Auditing: A Journal of Theory 8 Practice, Vol. 23, No. 2, pp. 89-103.

Brierley, J and Gwilliam, D. (2003). Human Resource Management Issues in Audit Firms: A Research Agenda. Managerial Auditing Journal, Vol. 18, No. 5, pp. 431-438.

Carlton, D.W. and Perloff, J.M. (2005). The Firm and Costs in Modern Industrial Organization, Edited by Carlton, D.W. and Perloff, J.M. 11-54, New York, NY: Addison Wesley.

Chung, H. and Kallapur. S. (2003). Client importance, non-audit services, and abnormal accruals. The Accounting Review, Vol. 78, No. 4, pp. 931-955.

Church, B and Zhang, P. (2002). Independence in Appearance: Non-auditing Services and Auditor Fee Disclosures, Working Paper, Toronto University.

Citron, D. (2003). The UK's Framework Approach to Auditor Independence and The Commercialization of The Accounting Profession, Accounting. Auditing and Accountability Journal, Vol. 16, No. 2, pp. 244-272.

Corless, J.C. and Parker, L.M. (1987). The Impact of MAS on Auditor Independence: An Experiment. Accounting Horizon, No. 1, pp. 25-29. 
Cullinan, L. (2004). Enron as A Symptom of Audit Process Breakdown: Can the Sarbones - Oxley Act Cure the Disease. Critical Perspectives on Accounting, Vol. 15, No. 617, pp. 853-864.

Davis, L.R, Ricchiute, D.N. and Trompeter, G.. (1993). Audit Effort, Audit Fees and the Provision of Non-Audit Services to Audit clients. The Accounting Review, January, 68, pp. 135-150.

DeAngelo, L.E. (1981). Auditor Independence, Low Balling, and Disclosures Regulation, Journal of Accounting and Economics, Vol. 3, pp. 183-199.

Defond, M. L., Raghunandan, K. and. Subramanyam K. R. (2002). Do non-audit service fees impair auditor independence? Evidence from going concern audit opinions. Journal of Accounting Research, Vol. 40, No. 4, pp. 1247-1274.

Defond, M. Raghunandan and Subramangam, K. (2002). Do Non-Audit Services Fees Impair Auditor Independence? Evidence from Going Concern Audit Opinions. Journal of Accounting Research, Vol. 40, pp. 1247-1273.

Dopuch, N., R. King, and R. Schwartz, (2003). Independence in Appearance and In Fact: An Experimental Investigation. Contemporary Accounting Research, Vol. 20, No. 1, pp. 79-115.

Elliott, R.K. and Jacabson, P. (1992). Audit independence: Concept and Application. The CPA journal, Vol. 62, No. 3, pp. 34-39.

Fearnley, S. and Beattie, V. (2004). The Reform of the UK's Auditor Independence Framework after the Enron Collapse: An Example of Evidence Based Policymaking. International Journal of Auditing, Vol. 8, pp. 117-138.

Flint. D. (1988). Philosophy and Principles of Auditing: An introduction, London, Macmillan Education LTD.

Frankel, R.M., Johnson, M.F. and Nelson, K.K. (2002). The Relation between Auditors' Fees for Non-Audit Services and Earnings Quality. The Accounting Review, Vol. 77, (supplement), pp. 71-105.

Geiger, M., and Raghunandan. K. (2003). Audit fees, non-audit fees, and auditor reporting on stressed companies. Auditing: A Journal of Practice and Theory, Vol. 22 (September), pp. 53-69.

Ghosh, A, Kallapur, S and Moon,D. (2006). Audit And Non-Audit Fees and Capital Market Perceptions of auditor Independence, working paper, baruch college.

Ghosh, A. and Moon, D. (2005). Auditor Tenure and Perceptions of Audit Quality. Accounting Review, Vol. 80, No. 2, pp. 585-612.

Glezen, G.W. and Millar. J.A (1985). An Empirical Investigation of Stockholder Reaction to Disclosures Required by ASR. No. 250, Journal of Accounting Research, Vol. 23, autumn, pp. 859-870.

Glezen, G.W. and Millar. J.A. (1985). An Empirical Investigation of Stockholder Reaction to Disclosures Required by ASR No. 250, Journal of Accounting Research, Vol. 23, autumn, pp. 859-870.

Gore, P., Pope P., and Singh. A. (2001). Non-audit services, auditor independence, and earnings management. Working paper: Lancaster University.

Gul F.A. and Yap, T.H. (1984). The Effects of Combined Audit and Management Services on Public Perception of Auditor Independence in Developing Countries the Malaysian Case. The International Journal of Accounting Education and Research, Vol. 20, No. 1, pp. 95-108.

Gul, F. (1989). Bankers' Perceptions of Factors Affecting Auditor Independence. Accounting, Auditing \& Accountability Journal, Vol. 2, No. 3, pp. 40-51.

Gul, F. and Tsui, J (1992). An Empirical Analysis of Hong Kong Bankers' Perceptions of Auditor Ability to Resist Management Pressure in an Audit Conflict Situation. Journal of International Accounting, Auditing and Taxation, Vol. 1, No. 2, pp. 177-190.

Gwilliam, D. (2003). Audit Methodology, Risk Management and Non-Audit Services, London, The Institute of Chartered Accountants, England and Wales.

Hackenbrack, K., and Elms. H. (2002), Mandatory disclosure and the joint sourcing of audit and non-audit services, Working Paper, University of Florida.

Higson, A. (2003). Corporate Financial Reporting: Theory and Practice, London: Sage Publication.

Independence Standard Board (ISB) (2000). Exposure Draft (Ed00-2), Statement of Independence Concepts: A Conceptual Framework for Auditor Independence, New York, NY.

Jenkins, J.G.; Krawczyk, K. (2001). The Relationship between Non-Audit Services and Perceived Auditor Independence, Working paper, North Carolina State. 
Karnishan J. and Levine, B (2004). Discipline with Common Agency: The Case of Audit and Non-Audit Services. Accounting Review, Vol. 79, No.1, pp. 173-200.

Kinney, W.R., Palmrose Z. and Schoolz, S. (2004). Auditor Independence, Non-Audit Services, and Restatements: Was the US Government Right? Journal of Accounting Research, Vol. 42, No. 3, pp. 561-588.

Knapp, M. (1985). Audit Conflict: An Empirical Study of the Perceived Ability of Auditors to Resist Management Pressure. The Accounting review, pp. 202-211.

Krishnan, G.V. (2005). Did Houston Clients of Arthur Andersen Recognize Publicly Available Bad News in a Timely Fashion? Contemporary Accounting Research, Vol. 22, No. 1, pp. 165-193.

Larcker, D.F. and Richardson, S.A. (2004). Fees paid to Audit Firms, Accrual Choices, and Corporate Governance. Journal of Accounting Research, Vol. 42, No. 3, pp. 625-658.

Larcker, D.F. and Richardson, S.A. (2004). Fees paid to Audit Firms, Accrual Choices, and Corporate Governance. Journal of Accounting Research, Vol. 42, No. 3, pp. 625-658.

Lee, A. (1993). Corporate Audit theory, Devon, Chapman and Hall.

Lennox, C. S. (1999). Non-audit fees, disclosure and audit quality. The European Accounting Review, Vol. 8, No. 2, pp. 239-252.

Mautz, R.K. and Sharaf, R. (1964). The Philosophy of Auditing, American Accounting Association, Sarasota, FL.

Mitchel, A., Sikka, P., Puxty, A and Wilmott, H. (1993). A Better Future for Auditing, London: University of East London

Muhamad, Z., and Karbhari, Y. (2006). Audit, Non-Audit Services and Auditor Independence, Staff Paper, Center of Excellence for Applied Financial and Accounting Studies Faculty of Economic and Management (University of Putra Malaysia).

O'Keefe, T.B., Simunic D.A.and Stein M.T. (1994). The Production of Audit Services: Evidence from a Major Public Accounting Firm. Journal of Accounting Research (autumn), pp. 241-261.

Orren, G. (1997). The appearance Standard on Audit Independence: What We Know and What We Should know? A Report Prepared on Behalf of the AICPA in Connection with the presentation to the Independence Standard Board.

Palmrose, Z.V. (1999). Empirical Research on Auditor Litigation Considerations and Data Sarasota, FL: AAA.

Pany, K and Reckers, P. (1988). Auditor Performance of MAS: A Study of Its Effects on Decisions and Perceptions. Accounting Horizons, June, pp. 31-8.

Quick, R. and Rasmussen, W. (2005). The Impact of MAS on Perceived Auditor Independence - Some Evidence from Denmark. Accounting Forum, Vol. 29, pp. 137-168.

Reynolds, J.K., Deis Jr., D.R. and Francis, J.R. (2004). Professional Service Fees and Auditor objectivity. Auditing: A Journal of Practice and Theory, Vol. 23, No. 1, pp. 29-52.

Securities and Exchange Commission (SEC). (2000). Revision of the Commission's Auditor Independence Requirements, (Releases No. 33-79919) (SEC, Washington, DC).

Sharma, D, S. (2006). Evidence on The Impact of Auditor Provided Non-Audit Services and Audit-firm tenure on Audit Efficiency, Working paper.

Shockley, RA. (1981). Perceptions of Auditors' Independence: An Empirical Analysis. The Accounting Review, No. 4, pp. 785-800.

Shu, S. (2000). Auditor Resignations: Client Effects and Legal Liability. Journal of Accounting and Economics, Vol. 29, pp. 173-205.

Sori, Z, M. (2006). Empirical Research Audit, Non-Audit services and Auditor Independence, Staff Paper the Malaysian Case. The International Journal of Accounting Education and Research, Vol. 20, No. 1, pp. 95-108.

Stevenson, J.E. (2002). Auditor Independence: A Comparative Descriptive Study of the UK, France and Italy. International Journal of Auditing, Vol. 6, pp. 155-182.

Sucher, P. and Maclullich, K. (2004). A Construction of Auditor Independence in the Czech Republic: Local Insights, Accounting. Auditing and Accountability Journal, Vol. 17, No. 2, pp. 276-305.

Teoh, H.Y. and Lim, E. (1996). An Empirical Study of the Effects of Audit Committees, Disclosure of Non-audit Fees and Other Issues on Audit Independence: Malaysian Evidence. Journal of International Accounting, Auditing and Taxation, Vol. 5, No. 2, pp. 231-48. 
Wahdan, Spronck, P., Ali, H., Waassen, E., and Hernick, H. (2005). Auditing in Egypt: A Study of Challenges, Problems and Possibility of an Automotive Formulation of Auditors Report. [Online] Available: WWW.CS.unimass.ni/p.spronck/rules.Wahdan.pdf

Wines, G.. (1994). Auditor Independence, Audit Qualifications and the Provision of Non-Audit Services. Accounting and Finance, Vol. 34, pp. 75-86.

Zeff, A. (2003a). How the US Accounting Profession Got Where It Is Today: part I. Accounting Horizons, Vol. 17, pp. 189-205.

Zeff, A. (2003b). How the US Accounting Profession Got Where It Is Today; part II. Accounting Horizons, Vol. 17, pp. 267-286.

Table 1. Respondent qualification

\begin{tabular}{|c|c|c|c|c|}
\hline \multirow{2}{*}{ Qualification } & \multicolumn{2}{|c|}{ Auditors } & \multicolumn{2}{c|}{ Shareholders } \\
\cline { 2 - 5 } & Frequency & Percent & Frequency & Percent \\
\hline Graduated & 178 & 78 & 236 & 25 \\
\hline Master & 47 & 1 & 0 & 0 \\
\hline PhD & 2 & 100 & 261 & 100 \\
\hline Total & 227 & & & 90 \\
\hline
\end{tabular}

Table 2. Auditing and accounting knowledge

\begin{tabular}{|l|l|l|l|l|}
\hline \multirow{2}{*}{ Auditing and accounting knowledge } & \multicolumn{2}{l|}{ Auditors } & \multicolumn{2}{l|}{ Shareholders } \\
\cline { 2 - 6 } & Yes & No & Yes & No \\
\hline Auditing Study & $98 \%$ & $2 \%$ & $60 \%$ & $40 \%$ \\
\hline Auditing \& Accounting Experience & $100 \%$ & $0 \%$ & $55 \%$ & $45 \%$ \\
\hline
\end{tabular}

Table 3. Factors affecting to audit independence

\begin{tabular}{|c|c|c|c|c|c|c|c|c|}
\hline \multirow{2}{*}{$\begin{array}{l}\dot{0} \\
\dot{Z} \\
\dot{n}\end{array}$} & \multirow{2}{*}{ Factors Affecting Independence } & \multirow{2}{*}{ 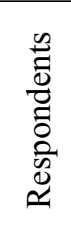 } & \multirow{2}{*}{ 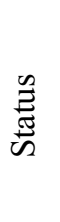 } & \multicolumn{2}{|c|}{$\begin{array}{c}\text { Paired Samples } \\
\text { Statistics }\end{array}$} & \multirow{2}{*}{$\begin{array}{c}\text { Paired Differences } \\
\text { Mean }\end{array}$} & \multicolumn{2}{|c|}{ Paired Samples Test } \\
\hline & & & & Mean & SD & & $\mathrm{Z}$ & Sig.* \\
\hline \multirow[b]{2}{*}{1} & \multirow[b]{2}{*}{ Bookkeeping } & \multirow[b]{2}{*}{488} & $\mathrm{Sh}$ & 2.79 & 1.185 & \multirow[b]{2}{*}{0.08} & \multirow[b]{2}{*}{-1.496} & \multirow[b]{2}{*}{0.135} \\
\hline & & & $\mathrm{A}$ & 2.71 & 1.372 & & & \\
\hline \multirow[t]{2}{*}{2} & \multirow{2}{*}{$\begin{array}{l}\text { Financial information systems } \\
\text { design }\end{array}$} & \multirow[t]{2}{*}{488} & Sh & 3.57 & 1.095 & \multirow[t]{2}{*}{0.66} & \multirow[t]{2}{*}{-11.695} & \multirow[t]{2}{*}{0.000} \\
\hline & & & $\mathrm{A}$ & 2.91 & 1.420 & & & \\
\hline \multirow[t]{2}{*}{3} & \multirow[b]{2}{*}{$\begin{array}{l}\text { Appraisal or valuation services } \\
\text { and fairness opinions }\end{array}$} & \multirow[b]{2}{*}{488} & $\mathrm{Sh}$ & 2.93 & 1.169 & \multirow[b]{2}{*}{0.39} & \multirow[b]{2}{*}{-7.170} & \multirow[b]{2}{*}{0.000} \\
\hline & & & A & 2.54 & 1.407 & & & \\
\hline \multirow[t]{2}{*}{4} & \multirow[t]{2}{*}{ Actuarial services } & \multirow[t]{2}{*}{488} & Sh & 2.47 & 1.358 & \multirow[t]{2}{*}{-0.04} & \multirow[t]{2}{*}{-0.790} & \multirow[t]{2}{*}{0.429} \\
\hline & & & A & 2.75 & 1.374 & & & \\
\hline \multirow[b]{2}{*}{5} & \multirow[b]{2}{*}{ Internal audit services } & \multirow[b]{2}{*}{488} & $\mathrm{Sh}$ & 2.51 & 1.256 & \multirow[b]{2}{*}{0.26} & \multirow[b]{2}{*}{-4.246} & \multirow[b]{2}{*}{0.000} \\
\hline & & & $\mathrm{A}$ & 2.49 & 1.392 & & & \\
\hline
\end{tabular}


Vol. 4, No. 2

International Journal of Business and Management

Table 4. Factors affecting to audit independence

\begin{tabular}{|c|c|c|c|c|c|c|c|c|}
\hline \multirow{2}{*}{$\begin{array}{l}\dot{z} \\
\dot{n}\end{array}$} & \multirow[b]{2}{*}{$\begin{array}{l}\text { Factors Affecting } \\
\text { Independence }\end{array}$} & \multirow{2}{*}{ 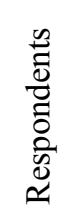 } & \multirow{2}{*}{ 志 } & \multicolumn{2}{|c|}{$\begin{array}{c}\text { Paired Samples } \\
\text { Statistics }\end{array}$} & \multirow{2}{*}{$\begin{array}{c}\text { Paired Differences } \\
\text { Mean }\end{array}$} & \multicolumn{2}{|c|}{ Paired Samples Test } \\
\hline & & & & Mean & SD & & Z & Sig.* \\
\hline \multirow[b]{2}{*}{1} & \multirow[b]{2}{*}{ Management functions } & \multirow[b]{2}{*}{488} & Sh & 3.92 & 1.116 & \multirow[t]{2}{*}{0.74} & \multirow[t]{2}{*}{-13.581} & \multirow[t]{2}{*}{0.000} \\
\hline & & & A & 3.18 & 1.076 & & & \\
\hline \multirow[b]{2}{*}{2} & \multirow[b]{2}{*}{ Human resources } & \multirow[b]{2}{*}{488} & Sh & 3.94 & 1.296 & \multirow[t]{2}{*}{0.46} & \multirow[t]{2}{*}{-9.340} & \multirow[t]{2}{*}{0.000} \\
\hline & & & A & 3.48 & 1.099 & & & \\
\hline \multirow[b]{2}{*}{3} & \multirow[b]{2}{*}{ Broker-dealer services } & \multirow[b]{2}{*}{488} & Sh & 3.62 & 1.049 & \multirow[b]{2}{*}{0.57} & \multirow[b]{2}{*}{-11.428} & \multirow[b]{2}{*}{0.000} \\
\hline & & & A & 3.05 & 1.200 & & & \\
\hline
\end{tabular}

